\title{
19. SHIPBOARD ORGANIC GEOCHEMISTRY AND SAFETY MONITORING, LEG 64, GULF OF CALIFORNIA ${ }^{1}$
}

\author{
Bernd R. T. Simoneit, ${ }^{2}$ Institute of Geophysics and Planetary Physics, University of California-Los Angeles, \\ Los Angeles, California
}

\begin{abstract}
1 have evaluated shipboard data and preliminary interpretations related to organic geochemistry in light of additional shore-based analyses. Data on interstitial gas, the $\mathrm{C} / \mathrm{N}$ ratio, and fluorescence indicate that organic matter was altered by sills and that these were all single intrusions except the upper sill complex at Site 481, which was a multiple emplacement. Site 477 had the highest in situ temperature, estimated from interstitial gas composition to be $225^{\circ} \mathrm{C}$.
\end{abstract}

\section{INTRODUCTION}

In order to avoid potential hydrocarbon traps, either stratigraphic or structural, the Joint Oceanographic Institutions for Deep Earth Sampling (JOIDES) reviewed proposed sites for Leg 64 according to available seismic and geological information. All were approved, with minor modifications, though Sites 479 and 480 were restricted to coring with real-time continuous monitoring of gas and fluorescence.

The shipboard geochemistry program was designed to monitor potential safety and pollution hazards from accumulations of gas and, secondarily, to provide data on the composition of organic matter plus additional samples for shore-based studies. This work consisted of observing core material under ultraviolet (UV) light, analyzing gases by gas chromatography (GC), determining the fluorescence behavior of solvent extracts, determining organic carbon and nitrogen content, and correlating sediment lithology with logging results.

We monitored interstitial hydrocarbon $\left(\mathrm{C}_{1}-\mathrm{C}_{7}\right)$ and fixed gases by GC, both on cores in real-time before proceeding with drilling and after core recovery. Gas was present at Sites 474 and 477 through 481 . Data summaries, which appear in the site chapters (this volume, Pt. 1), correlate quantities of various compounds with depth and are useful in evaluating the presence of biogenic versus thermogenic gas, drilling safety, and pollution prevention.

Organic carbon and nitrogen and calcium carbonate contents were determined aboard ship using the $\mathrm{CHN}$ analyzer and the Carbonate Bomb method. We used the $\mathrm{C} / \mathrm{N}$ ratio to monitor extreme thermal stress on the organic matter; data appear in Appendix I as well as in the site chapters. Fluorescence of sediment extracts, which had been dried and pyrolyzed, was determined (Wyman and Castaño, 1974) to gauge petroleum-generating potential and the amount of geothermally expelled petroliferous material. These data are also found in the site chapters.

\footnotetext{
${ }^{1}$ Curray, J. R., Moore, D. G., et al., Init. Repts. DSDP, 64: Washington (U.S. Govt.
} Printing Office).

2 Present address: School of Oceanography, Oregon State University, Corvallis, Oregon.

\section{EXPERIMENTAL METHODS}

We sampled gas pockets in the cores through the liner with a syringe, along with pressure build-up under the core caps. Samples were injected into vacutainers (evacuated test tubes) and analyzed for $\mathrm{CH}_{4}$ and $\mathrm{CO}_{2}$ (with an estimate of $\mathrm{C}_{2} \mathrm{H}_{6}$ and $\mathrm{H}_{2} \mathrm{~S}$ ) on the Carle gas chromatograph and, for more detailed hydrocarbons $\left(\mathrm{C}_{2}-\mathrm{C}_{7}\right)$, on the Hewlett-Packard Model 5710A gas chromatograph. Both instruments were fitted with a Columbia Scientific Model CSI 38 digital integrator. Detailed experimental procedures are given in the Site 474 site chapter this volume, Pt. 1.

\section{RESULTS AND DISCUSSION}

Maximum concentrations of $\mathrm{C}_{1}-\mathrm{C}_{5}$ hydrocarbons in the interstitial gas at each site are summarized in Table 1. The highest values for ethane were observed at Sites 477 and 481 , where the $C_{2} / C_{1}$ ratio was equal to $100 \times$ $10^{-4}$ and $64 \times 10^{-4}$, respectively. Concentrations of the butanes and pentanes were relatively high, however (Site $481 \gg$ Site 477), indicating that the $C_{2} / C_{1}$ criterion for source of gases is not always reliable (cf. Whelan and Sato, 1980).

Biogenic hydrocarbons in interstitial gas can be characterized by the ratio $C_{1} /\left(C_{2}+C_{3}\right)$ with values exceeding 1000, and petrogenic (i.e., thermogenic) hydrocarbons can be categorized by the ratio $C_{1} /\left(C_{2}+C_{3}\right)$ with values less than 50 (Bernard et al., 1976). Examples

Table 1. Maximum concentrations of $\mathrm{C}_{1}-\mathrm{C}_{5}$ hydrocarbons, Leg 64.

\begin{tabular}{|c|c|c|c|c|c|}
\hline Site & $\begin{array}{l}\mathrm{CH}_{4} \\
(\%)\end{array}$ & $\begin{array}{l}\mathrm{C}_{2} \mathrm{H}_{6} \\
(\%)^{\mathrm{a}}\end{array}$ & $\begin{array}{l}\mathrm{C}_{3} \mathrm{H}_{8} \\
(\%)^{\mathrm{a}}\end{array}$ & $\begin{array}{c}\mathrm{C}_{4} \mathrm{H}_{10} \\
(\%)^{\mathrm{a}}\end{array}$ & $\begin{array}{c}\mathrm{C}_{5} \mathrm{H}_{12} \\
(\%)^{\mathrm{a}}\end{array}$ \\
\hline 474 & 98.8 & 0.08 & 0.017 & 0.007 & - \\
\hline 475 & $\begin{array}{c}\text { no gas } \\
\text { observed }\end{array}$ & - & - & - & - \\
\hline 476 & $\begin{array}{c}\text { no gas } \\
\text { observed }\end{array}$ & - & - & - & - \\
\hline 477 & 93.2 & 0.5 & 0.040 & 0.003 & - \\
\hline 478 & 97.2 & 0 & 7 & .001 & - \\
\hline 479 & 92 & 0.122 & 10 & 0.016 & 0.0015 \\
\hline 480 & 91.8 & 0.035 & 0.003 & 0.0003 & - \\
\hline 481 & 98.7 & 0.634 & 0.024 & 0.015 & 0.022 \\
\hline
\end{tabular}

Note: Dashes $=$ not detected.

a Based on $100 \%$ methane; includes all isomers. 
of maximum and minimum values for the Leg 64 sites appear in Table 2. The biogenic gas in the shallow sediments of Sites $474,477,479$, and 481 has $C_{1} /\left(C_{2}+C_{3}\right)$ values $>10,000$, with $C_{2} / C_{1}$ values ranging from 0.3 to $7.0 \times 10^{-4}$. The thermogenic gas component is not predominant at any of these four sites (i.e., the $C_{1} /\left[C_{2}\right.$ $+\mathrm{C}_{3}$ ] values are not $<50$ ); therefore, the interstitial gas at depth was described as a mixture of biogenic and thermogenic components. It should be noted, however, that some hydrocarbons-for example, neopentanemay be generated from biogenic organic detritus by very low thermal stress, and as the temperature increases they are in turn cracked further. Such molecules may be differently interpreted by various authors as to their genetic origin (e.g., Whelan, this volume, Pt. 2). For Sites 477 and 481 , the $C_{1} /\left(C_{2}+C_{3}\right)$ values are 157 and 316 , respectively, indicating a substantial thermogenic component.

The gas at depth at Site 481 was qualitatively the same (also in odor) as gas liberated from gravity core samples taken in 1972 at a site about $8 \mathrm{~km} \mathrm{NE}$ (SIO Hypogene Cruise, Site 30G; Simoneit et al., 1979). The $\mathrm{C}_{1} /\left(\mathrm{C}_{2}+\mathrm{C}_{3}\right)$ values for the $30 \mathrm{G}$ samples were between 41 and 149 , and the cores may have experienced some loss of $\mathrm{CH}_{4}$ and $\mathrm{C}_{2} \mathrm{H}_{6}$ during storage (Simoneit et al., 1979). Thus the interstitial hydrocarbon gas at Site 481 is comparable to that at shallower depth at the site $8 \mathrm{~km}$ to the northeast in this northern basin, and both are of a thermogenic origin.

The interstitial gas at Site 474 was primarily of a biogenic origin throughout the hole, consisting of $\mathrm{CO}_{2}$, $\mathrm{CH}_{4}, \mathrm{C}_{2} \mathrm{H}_{6}$, and $\mathrm{C}_{3} \mathrm{H}_{8}$, with $\mathrm{H}_{2} \mathrm{~S}$ present in the upper section and exhibiting maximum concentrations at about 300 meters sub-bottom. The $\mathrm{C} / \mathrm{N}$ values range from 12 to 17 , well within those typical of immature and recent marine sediments (Ryther, 1956). No gas was present at Sites 475 and 476 , and the $\mathrm{C} / \mathrm{N}$ data also indicated typical marine values.

The interstitial gas at Site 477 (Table 3) was of a thermogenic origin below the upper sill and consisted of $\mathrm{CO}_{2}, \mathrm{CH}_{4}, \mathrm{C}_{2} \mathrm{H}_{6}$, and $\mathrm{C}_{3} \mathrm{H}_{8}$; the distribution of the $\mathrm{C}_{1}-\mathrm{C}_{3}$ hydrocarbons indicated virtually complete hightemperature cracking of the $>\mathrm{C}_{4}$ hydrocarbons. This high temperature was further corroborated by the nitrogen content of the organic matter. At depths exceeding 150 meters, the $\mathrm{C} / \mathrm{N}$ ratio increased to infinity (Fig. 1), indicating that all the nitrogen had been expelled (sug-

Table 2. Various ratios of $C_{1}-C_{5}$ hydrocarbons, Leg 64 .

\begin{tabular}{lccr}
\hline \multicolumn{1}{c}{ Section } & $\mathrm{C}_{2} / \mathrm{C}_{1} \times 10^{-4}$ & $\mathrm{C}_{1} /\left(\mathrm{C}_{2}+\mathrm{C}_{3}\right)$ & $\mathrm{C}_{1} /\left(\mathrm{C}_{2}-\mathrm{C}_{5}\right)$ \\
\hline $478-8-3^{\mathrm{a}}$ & 0.56 & 16,050 & 16,050 \\
$474 \mathrm{~A}-11-3^{\mathrm{b}}$ & 5.65 & 1,470 & 1,380 \\
$477-5-1^{\mathrm{a}}$ & 0.30 & 22,500 & 20,810 \\
$477-17-3^{\mathrm{b}}$ & 59.6 & 157 & 156 \\
$479-3-2^{\mathrm{a}}$ & 0.50 & 17,430 & 17,430 \\
$479-44-2^{\mathrm{b}}$ & 18.8 & 1,020 & 878 \\
$481 \mathrm{~A}-4-1^{\mathrm{a}}$ & 7.0 & 15,070 & 12,330 \\
$481 \mathrm{~A}-12-5^{\mathrm{b}}$ & 64.4 & 316 & 302 \\
\hline
\end{tabular}

\footnotetext{
a Biogenic gas.

$\mathrm{b}$ Biogenic gas with admixed thermogenic gas.
}

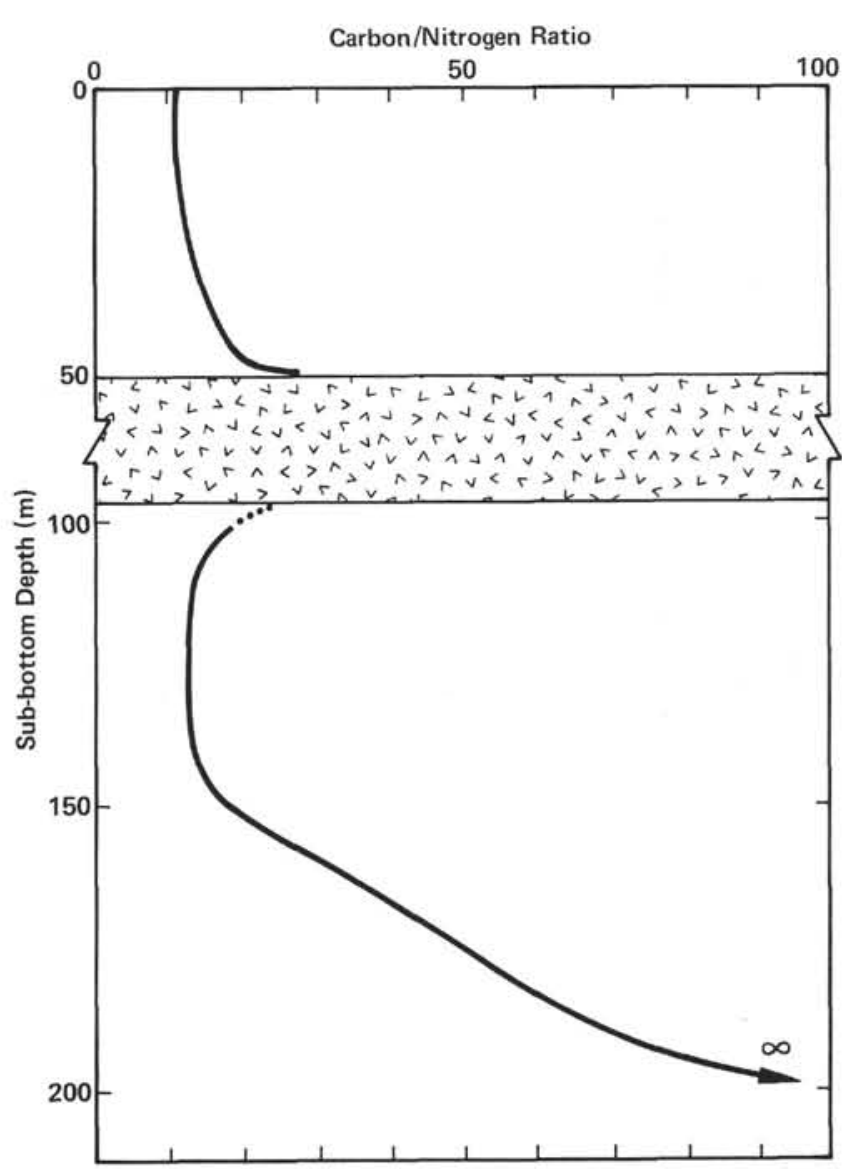

Figure 1. Atomic carbon to nitrogen ratios (organic) versus depth for samples from Holes 477 and $477 \mathrm{~A}$.

gesting temperatures $>550^{\circ} \mathrm{C}$; Simoneit et al., unpublished results). There was also an increase in the $\mathrm{C} / \mathrm{N}$ ratio, with a decrease just below the upper sill, confirming that the sill is an intrusion and not a flow; that is, the organic matter was thermally stressed on both sides of the sill.

At Site 478, the interstitial gas was primarily of a biogenic origin above the upper sill, perhaps with a thermogenic component below about 160 meters. Between the sills, the gas consisted of a fully cracked thermogenic mixture (see site chapter; this volume, Pt. 1). The $\mathrm{C} / \mathrm{N}$ data do not show the effect of the thermal stresses caused by the various intrusions, but fluorescence analysis of the bitumen does confirm the intrusive events (Fig. 2A). The bitumen was distilled away, both above and below the sills; this had also been observed in an intruded Cretaceous black shale at Site 368 (Simoneit et al., 1978).

The interstitial gas at Site 479 was primarily biogenic to a depth of about 250 meters, consisting of $\mathrm{CH}_{4}, \mathrm{CO}_{2}$, $\mathrm{H}_{2} \mathrm{~S}$, and minor amounts of $\mathrm{C}_{2} \mathrm{H}_{6}$ (Fig. 3). Below that, the sediments became more indurated and the $\mathrm{C}_{2}-\mathrm{C}_{5}$ hydrocarbon content of the interstitial gas increased rapidly (Fig. 3). Propane and isobutane attained a concentration maximum at about 400 meters sub-bottom, and isopentane appeared to be increasing to a maximum below that depth. These data indicate that heavier hydrocarbons $\left(>C_{2}\right)$ were diffusing upward from depth according to their boiling points and that, at greater 

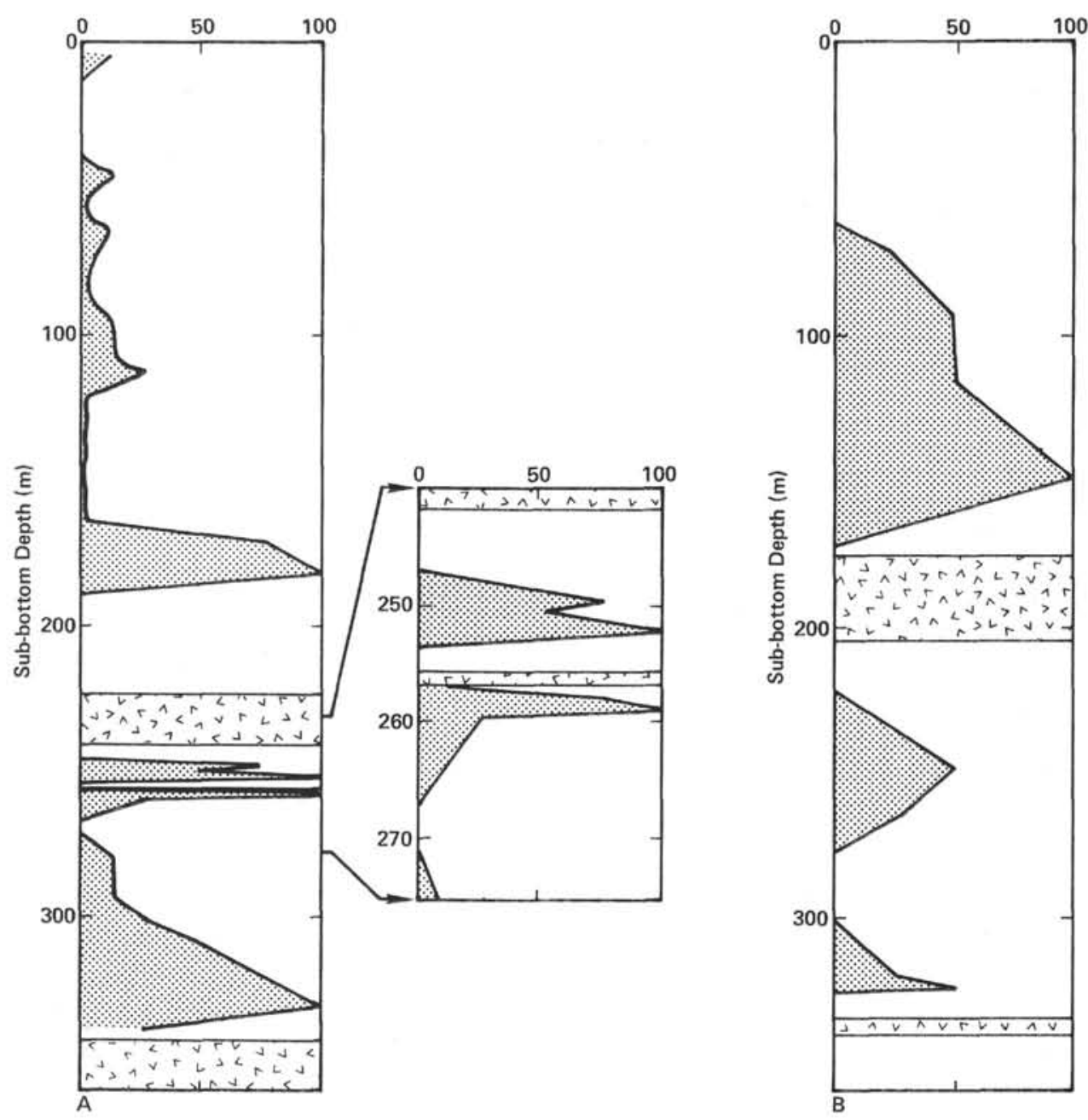

Figure 2. Relative fluorescence of trichloroethane extracts of dried sediment samples versus depth. (A) Hole 478; (B) Hole 481A.

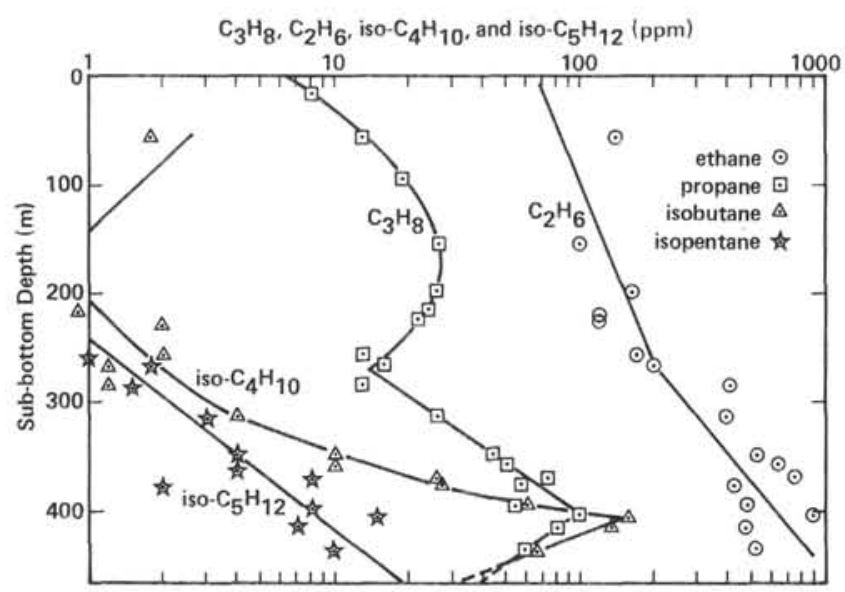

Figure 3. Concentrations versus depth of interstitial hydrocarbon gases at Site 479 (ppm by volume, assuming $\mathrm{CH}_{4}=100 \%$ ).

depths, the higher weight hydrocarbons $\left(>\mathrm{C}_{5}\right.$ ) would be encountered, possibly even in traps. Migration of light hydrocarbons through shales by diffusion has been demonstrated by Leythaeuser et al. (1979). The C/N values and fluorescence data indicated that the bulk of the organic matter is immature.

The interstitial gas at Site 480 was mainly biogenic, consisting of $\mathrm{CH}_{4}, \mathrm{CO}_{2}, \mathrm{H}_{2} \mathrm{~S}$, and lesser amounts of $\mathrm{C}_{2} \mathrm{H}_{6}$. Since the sediment lithology is similar to that at Site 479 , the more rapid increase of the $C_{2} / C_{1}$ value at this site may indicate a slightly more rapid upward migration rate of thermogenic hydrocarbons. The $\mathrm{C} / \mathrm{N}$ data for the site indicate that the bulk of the organic matter is immature.

Site 481 is about $8 \mathrm{~km}$ southwest of Gravity Core 30G (Simoneit et al., 1979), and the thermogenic gas composition was essentially the same for both sites. The $\mathrm{C}_{3}-\mathrm{C}_{5}$ hydrocarbons above the sill at Site 481 exhibited multiple maxima (Einsele et al., 1980), whereas $\mathrm{CH}_{4}$ and $\mathrm{C}_{2} \mathrm{H}_{6}$ had a broad maximum at the same depth. These data, coupled with the fluorescence results showing a broad bitumen distribution above the upper sill (Fig. 2B), indicate a multiple emplacement of this sill. The $\mathrm{C} / \mathrm{N}$ data (Fig. 4) suggest the presence of some unaltered sediment above the upper sill as well as right below it. Though this observation does not fit with the interpretation just offered, it may indicate slumping and 


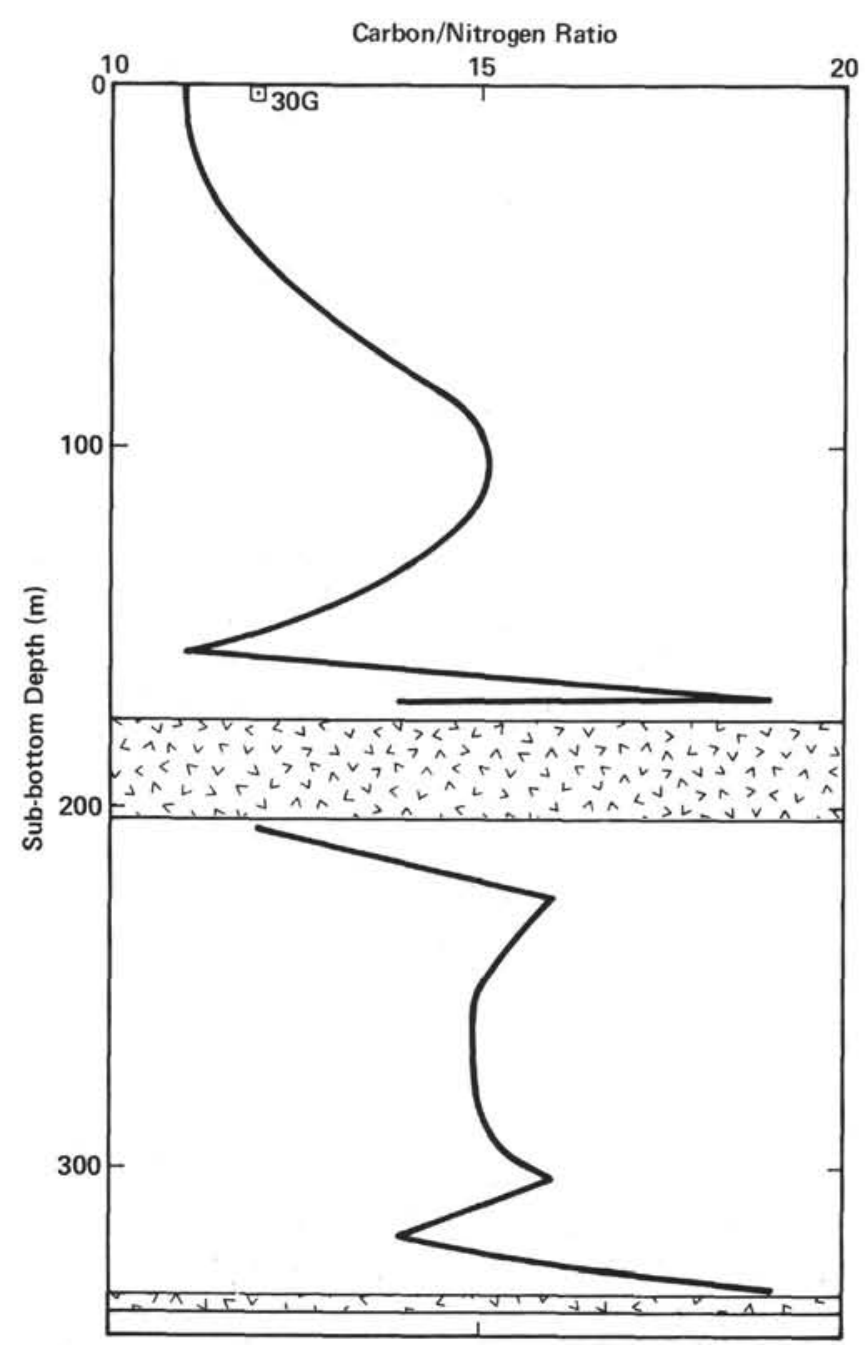

Figure 4. Atomic carbon to nitrogen ratios (organic) versus depth for samples from Holes 481 and $481 \mathrm{~A}$. (The point labeled 30G is a surface sample located $8 \mathrm{~km}$ NE [Simoneit et al., 1979].)

reworking of sediment during the intrusive events. Below the upper sill, gas composition, fluorescence, and $\mathrm{C} / \mathrm{N}$ values do reflect the elevated thermal stress caused by the lower sill.

\section{Gas Geothermometry}

The gas assemblage $\mathrm{CO}_{2}-\mathrm{H}_{2} \mathrm{~S}-\mathrm{CH}_{4}-\mathrm{H}_{2}-\mathrm{N}_{2}$ always occurs in or near thermal areas (D'Amore and Panichi, 1980). Using the chemical composition of gases emanating from thermal areas, these authors evaluated deep thermal temperatures and developed an empirical relationship in which

$$
\begin{aligned}
t^{\circ} \mathrm{C} & =\frac{24,775}{\alpha+\beta+36.05}-273, \text { where } \\
\alpha & =2 \log \frac{\mathrm{CH}_{4}}{\mathrm{CO}_{2}}-6 \log \frac{\mathrm{H}_{2}}{\mathrm{CO}_{2}}-3 \log \frac{\mathrm{H}_{2} \mathrm{~S}}{\mathrm{CO}_{2}}
\end{aligned}
$$

(concentrations expressed in $\%$ by volume), and

$$
\beta=7 \log \mathrm{P}_{\mathrm{CO}_{2}} \text {. }
$$

It would be of interest to attempt such calculations for representative gas compositions from Site 477, where the temperature at depth is still high. The analytical data determined on board with the Carle gas chromatograph had to be utilized, because the $\mathrm{H}_{2} \mathrm{~S}$ had been adsorbed by the stoppers of the vacutainers in storage. The concentration of hydrogen was estimated by difference, after adding $\mathrm{CO}_{2}, \mathrm{CH}_{4}$, air, $\mathrm{C}_{2} \mathrm{H}_{6}$, and $\mathrm{H}_{2} \mathrm{~S}$, and this estimate can introduce a major error into temperature calculation. The concentrations of the gases (vol.\%) for two examples are found in Table 3. Gas in Section 477-5-1 (29.5 m sub-bottom) was shown to be of biogenic origin and the value of $\alpha+\beta$ equal to 34.4. This corresponds to a temperature of $75^{\circ} \mathrm{C}$ as estimated from the theoretical line in Figure 5. Though this seems high, it is in the correct range for situations in which the empirical data pertain to hydrothermal systems. Data for Section 477-19-2 (145.5 m sub-bottom) are also given in Table 3, and this gas composition is of a primarily thermogenic origin. The sum of $\alpha+\beta$ is 14.1 , corresponding to a temperature of $225^{\circ} \mathrm{C}$, again as estimated from the theoretical line of Figure 5. This temperature is in reasonable agreement with shipboard measurements and estimates but should be taken with caution and as an approximation only, primarily because of our uncertainty over the figures for $\mathrm{H}_{2}$ and $\mathrm{H}_{2} \mathrm{~S}$. In future encounters with such thermogenic gas, it would be useful to determine hydrogen data while aboard ship and also to better quantify the $\mathrm{H}_{2} \mathrm{~S}$ concentration. This would further test the applicability of this empirical approach to the evaluation of in situ temperatures.

\section{Residual Carbon Black}

A black or brown-black slick permeated the voids in Hole 477, Cores 19-23; Hole 477A, Cores 5-10; and Hole 478, Cores 28-40. This slick was hydrophobic, less dense than water, odorless, and did not fluoresce. We determined that the material was primarily very fine, highly surfactive, particulate carbon, which had adsorbed large quantities of interstitial gas, making it

Table 3. Gas composition and computed temperature for two examples from Site 477.

\begin{tabular}{lcc}
\hline & $\begin{array}{c}\text { Section } 477-5-1 \\
(29.5 \text { m sub-bottom })\end{array}$ & $\begin{array}{c}\text { Section } 477-19-2 \\
(145.5\end{array}$ \\
& 7 & 43.9 \\
$\mathrm{CO}_{2}(\%)$ & 56 & 38.2 \\
$\mathrm{CH}_{4}(\%)$ & 36 & 4.0 \\
$\mathrm{Air}\left(\mathrm{N}_{2}+\mathrm{O}_{2}\right)(\%)$ & - & 0.3 \\
$\mathrm{C}_{2} \mathrm{H}_{6}(\%)$ & 1 & 3.0 \\
$\mathrm{H}_{2} \mathrm{~S}(\%)$ & 0.001 & 10.6 \\
$\mathrm{H}_{2}(\%)^{\mathrm{a}}$ & 27.4 & 7.1 \\
$\alpha$ & 7 & 7 \\
$\beta^{\mathrm{b}}$ & 75 & 225 \\
$t^{\circ} \mathrm{C}^{\mathrm{C}}$ & 75 & \\
\hline
\end{tabular}

a Calculated by difference from summation of $\mathrm{CO}_{2}, \mathrm{CH}_{4}$, air, $\mathrm{C}_{2} \mathrm{H}_{6}$, and $\mathrm{H}_{2} \mathrm{~S}$; for $\mathrm{H}_{2}=0$ used recommended $0.001 \%$ (D'Amore and Panichi, 1980).

b For $\mathrm{CO}_{2}$ concentration $<75 \%$ (by volume) the $\mathrm{PCO}_{2}$ is assumed to be $0.1 \mathrm{~atm}$. (D'Amore and Panichi, 1980).

${ }^{\mathrm{c}}$ Estimated from the theoretical line of Figure 5. 


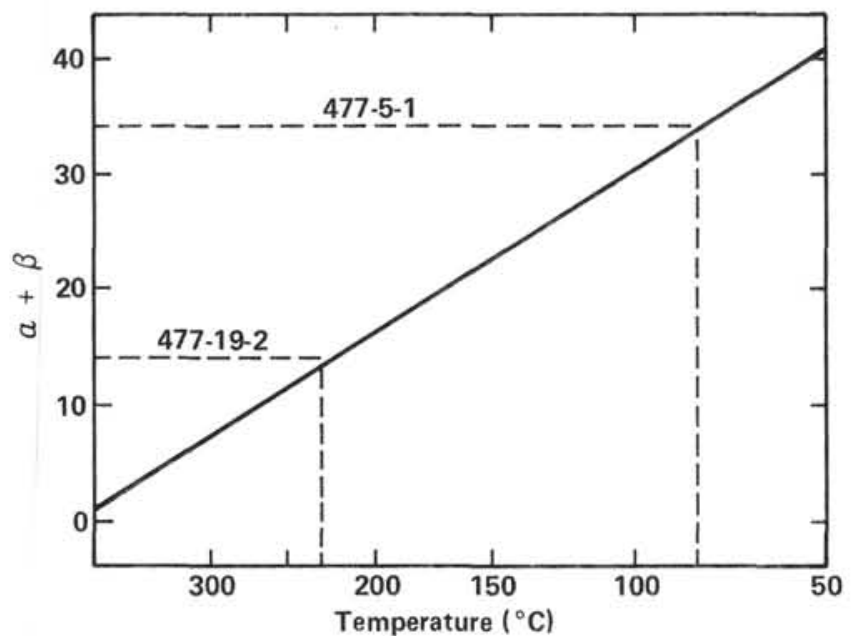

Figure 5. Theoretical straight line for $(\alpha+\beta)$ versus temperature (D'Amore and Panichi, 1980). Two samples from Site 477 are indicated.

hydrophobic. The $\mathrm{C} / \mathrm{N}$ ratio was 86 for a sample from Site 477 and 22 for one from Site 478 , indicating that the sample from 478 had been less severely heated. This carbonaceous matter represents the in situ pyrolysis residue of the sedimentary kerogen. If one compares these $\mathrm{C} / \mathrm{N}$ data with laboratory simulations of thermal maturation experiments, one finds that the temperature required to attain $\mathrm{C} / \mathrm{N}>40$ exceeds $500^{\circ} \mathrm{C}$ (Simoneit, unpublished results). Pyrolysis-gas chromatography of this carbonaceous matter also confirms that all volatilizable material has been driven out-i.e., it is a pyrolysis residue (Philp and Simoneit, this volume, Pt. 2).

We also observed the effects of high temperature in Hole 477A, during the operational hold for the analysis of the black slick, when we found that the core liner of Core 12 was deformed by partial melting in spite of circulating drilling fluid. The butyrate plastic used for the core liner softens at about $85^{\circ} \mathrm{C}$ and melts at about $135^{\circ} \mathrm{C}$.

\section{CONCLUSION}

Shipboard data on organic geochemistry and preliminary interpretations correlate with shore-based analyses and supplemental data. The organic matter at Site 477 below the upper sill had been hydrothermally altered by the deep heat source below the bottom of the hole. The $\mathrm{C} / \mathrm{N}$ and interstitial gas data confirm this high thermal stress, and the $\mathrm{C} / \mathrm{N}$ data also show that the up- per sill $(50-100 \mathrm{~m})$ is an intrusion and not a flow. A temperature of $225^{\circ} \mathrm{C}$ could be estimated for the thermal area $(\sim 145 \mathrm{~m})$ based on the interstitial gas composition. It would be useful to quantitate $\mathrm{H}_{2}$ and $\mathrm{H}_{2} \mathrm{~S}$ along with $\mathrm{CH}_{4}, \mathrm{CO}_{2}$, and $\mathrm{C}_{2} \mathrm{H}_{6}$ in future samples of hydrothermal gas. At Sites 478 and 481 , the multiple intrusions had only limited effects on the organic matter in proximity to the sills. Based on the interstitial gas, $\mathrm{C} / \mathrm{N}$, and fluorescence data for Site 478, we interpret the upper two sills $(\sim 220 \mathrm{~m}, \sim 255 \mathrm{~m})$ as separate intrusive events, whereas the upper sill complex $(\sim 150-200 \mathrm{~m})$ at Site 481 seems to have been emplaced by multiple (at least three, sequential, upward) intrusive pulses, and the lower sill $(\sim 330 \mathrm{~m})$ was a single intrusion. The organic matter of the other sites consists primarily of immature marine detritus, except at Site 479, where gasoline range hydrocarbons are diffusing upward (according to their boiling points) through the sediment sequence from a deeper source.

\section{ACKNOWLEDGMENTS}

I thank the staff of the Deep Sea Drilling Project and the National Science Foundation for making possible my participation on Leg 64.1 also thank the crew of the Glomar Challenger and the technical support staff, especially J. Pine, for their assistance during the cruise and K. A. Kvenvolden for review of this manuscript. This is contribution No. 2063 from the Institute of Geophysics and Planetary Physics, University of California-Los Angeles.

\section{REFERENCES}

Bernard, B. B., Brooks, J. M., and Sackett, W. M., 1976. Natural gas seepage in the Gulf of Mexico. Earth Planet. Sci. Lett., 31:48-54.

D'Amore, F., and Panichi, C., 1980. Evaluation of deep temperatures of hydrothermal systems by a new gas thermometer. Geochim. Cosmochim. Acta, 44:549-556.

Einsele, G., Gieskes, J. M., Curray, J., et al., 1980. Intrusion of basaltic sills into highly porous sediments, and resulting hydrothermal activity. Nature, 283:441-445.

Leythaeuser, D., Schaefer, R. G., Cornford, C., et al., 1979. Generation and migration of light hydrocarbons $\left(C_{2}-C_{7}\right)$ in sedimentary basins. Org. Geochem., 1:191-204.

Ryther, J. H., 1956. Photosynthesis in the ocean as a function of light intensity. Limnol. Oceanogr., 1:6-70.

Simoneit, B. R. T., Brenner, S., Peters, K. E., et al., 1978. Thermal alteration of Cretaceous black shale by basaltic intrusions in the Eastern Atlantic. Nature, 273:501-504.

Simoneit, B. R. T., Mazurek, M. A., Brenner, S., et al., 1979. Organic geochemistry of Recent sediments from Guaymas Basin, Gulf of California. Deep-Sea Res., Part A, 26:879-891.

Whelen, J. K., and Sato, S., 1980. C $1-C_{5}$ hydrocarbons from core gas pockets-Deep Sea Drilling Project Legs 56 and 57, Japan Trench. In Scientific Party, Init. Repts. DSDP, 56, 57, Pt. 2: Washington (U.S. Govt. Printing Office), 1335-1348.

Wyman, R. E., and Castaño, J. R., 1974. Show descriptions from core, sidewall and ditch samples. Trans. SPWLA Annu. Logging Symp., 15:1-21. 